American Journal of Environmental Sciences 6 (3): 295-298, 2010

ISSN 1553-345X

(C) 2010 Science Publications

\title{
Demonstration Case of Petrochemical Wastewater Treatment Plant
}

\author{
${ }^{1}$ Saad Abualhail, ${ }^{2}$ Rusul Naseer and ${ }^{1} \mathrm{Xi}-\mathrm{Wu} \mathrm{Lu}$ \\ ${ }^{1}$ Department of Environmental Science and Engineering, \\ School of Energy and Environmental, Southeast University, \\ Nanjing 210096, China \\ ${ }^{2}$ Department of Chemical Engineering, College of Engineering, \\ Basrah University, Iraq
}

\begin{abstract}
Problem statement: The wastewater from petrochemical complex is varying in flow, organic contaminant loading and composition due to various operating condition of the petrochemical complex. This study is demonstration case of petrochemical wastewater treatment plant. Approach: This study is demonstration case on Basrah petrochemical wastewater treatment plant whereas the description of wastewater composition and system of treatment had reviewed and the experimental work on the most important control parameters (F/M ratio and MCRT) had implemented. Results: The experimental results showed that (i) The optimum rate of BOD removal could be obtained at food to microorganism ratio between 0.1-0.15 where this optimum ratio exists at the maximum zone settling velocity (ii) The design effluent BOD5 could be obtained at a MLSS concentration of $6000 \mathrm{mg} \mathrm{L}^{-1}$ and in about 26-30 day of mean cell residence time Conclusion: The experimental data from petrochemical wastewater treatment plant in Basra City (south of Iraq) showed that the extended Aeration offers the most desirable features for the treatment of petrochemical wastewater where the specification of this method apply with experimental results as well as that the study show that control parameters (F/M ratio and MCRT) is a good tool to control the effluent wastewater quality of petrochemical wastewater treatment plant.
\end{abstract}

Key words: Petrochemical wastewater, control parameter, petrochemical complex

\section{INTRODUCTION}

The Basrah Petrochemical Complex consists of the following process units and supporting facilities:

- Ethane Recovery and Ethylene

- Chlorine Caustic

- Viny1 Chloride Monomer

- Polyvinyl chloride

- Low density Polyethylene

- High density polyethylene

- Off site facilities

Owing to varieties of biological treatment processes were used in the treatment of Petrochemical wastewater, this study will discuss the most desirable methods among all these methods that had used for the same purpose whereas the most commonly processes that used for petrochemical wastewater are aerated lagoon, oxidation ditch, extended Aeration, TF and RBC (Orhon et al., 2009; Clescerl et al., 1991).
Trickling Filter (TF) is not efficient for removal of BOD. While the Rotating Biological Contractor (RBC) has gained wider use in recent years, its application to the petrochemical wastewater treatment is, however, somewhat limiting (Tchobanoglous et al., 2002).

To achieve if Extend Aeration process is most desirable process for petrochemical wastewater or not, the experimental work on control parameters F/M ratio and MCRT will be studied.

The $F / M$ ratio is one of the process control parameters that can monitor on activated sludge system (Ralph and Blackburn, 1997). The optimum F/M ratio for any plant can only be determined by monitoring facility performance through regular process control testing. In a biological wastewater treatment process, Mean Cell Residence Time (MCRT) refers to the average time that microorganisms remain inside a biological system. Selection of a suitable MCRT is important for successful operation of Activated Sludge Process (ASP). MCRT not only controls the biomass concentration inside the ASP, but more importantly, it determines the settling characteristics of the biomass.

Corresponding Author: $\mathrm{Xi}-\mathrm{Wu} \mathrm{Lu}$, Department of Environmental Science and Engineering,

School of Energy and Environmental, Southeast University, Nanjing 210096, China 
Am. J. Environ. Sci., 6 (3): 295-298, 2010

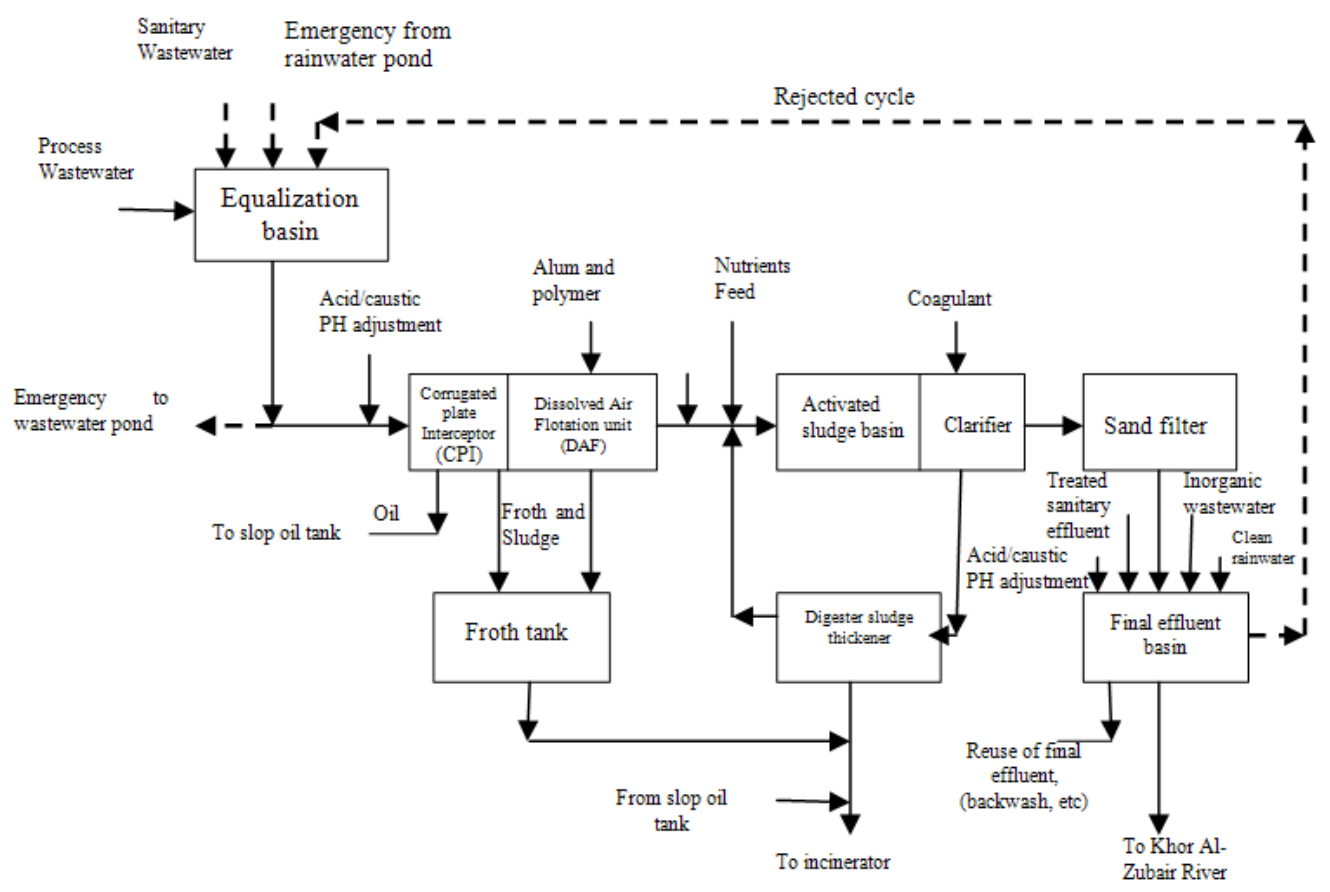

Fig 1: Block flow diagram of biological wastewater treatment system in basrah petrochemical complex

\section{MATERIALS AND METHODS}

System description: Figure 1 is block flows diagram that depicting the biological wastewater treatment system of the complex. The process wastewater is collected in the equalization basin. Additional surge capacity, approximately $15 \%$ of the equalization capacity is provided for infrequent flow of contaminant rainwater. Provisions are made for PH monitoring and adjustment for the flow from the equalization basin to the CPI Oil Separator.

The primary treatment step consists of a Corrugated Plate Interceptor (CPI) unit for the free oil and suspended solids removal and a Dissolved Air Flotation (DAF) unit for removal of emulsified Oils. Alum and Polymer feed systems are provided at the DAF unit to facilitate effective separation and flotation of emulsified oils.

The decanted oil and float as well as the bottom sludge from the CPI and DAF units are collected in the slop tank and froth tank respectively and dispose of by incineration.

The secondary treatment step is Extended Aeration Activated sludge system. The Aeration basin has four compartments, each with a capacity of $580 \mathrm{~m}^{3}$. In Normal operation three of four compartments are in use, leaving the fourth is empty for possible influent surge flow. Mechanical Surface Aerator at 18.6 KW capacities is provided for each basin.
Table 1: Influent wastewater characteristics

\begin{tabular}{lll}
\hline \multicolumn{3}{l}{ Of Basrah petrochemical complex } \\
\hline Flow & $\mathrm{m}^{3} \mathrm{~h}^{-1}$ & $125-200$ \\
BOD $_{5}$ & $\mathrm{mg} \mathrm{L}^{-1}$ & $150-670$ \\
COD & $\mathrm{mg} \mathrm{L}^{-1}$ & $570-2100$ \\
Oil & $\mathrm{mg} \mathrm{L}^{-1}$ & $50-80$ \\
TSS & $\mathrm{mg} \mathrm{L}^{-1}$ & $1520-1800$ \\
TDS & $\mathrm{mg} \mathrm{L}^{-1}$ & $3400-6000$ \\
Phenols & $\mathrm{mg} \mathrm{L}^{-1}$ & $0.5-1$ \\
Sulfides & $\mathrm{mg} \mathrm{L}^{-1}$ & $0.14-1$ \\
\hline
\end{tabular}

Characteristics of wastewater: Wide range of variations in the influent wastewater flow and concentration of pollutants had been tested in the laboratory of Basrah petrochemical Complex for period (1980-2002) is shown in Table 1.

Control relationship model: The relationships to be considered in the following discussion include the specific utilization rate, mean cell residence time and the \{food/Microorganism\} ratio. The relationship between the specific Utilization rate (U) and mean cell residenceresidence time is also examined (Melcer, 2003):

$$
\mathrm{U}=-\frac{\mathrm{r}_{\mathrm{su}}}{\mathrm{x}_{\mathrm{v}}}=\frac{\mathrm{s}_{\mathrm{o}}-\mathrm{s}}{\left(\mathrm{t}_{\mathrm{an}}+\mathrm{t}_{\mathrm{agy}}\right)(\mathrm{xy})}=\left(\frac{\mathrm{Q}}{\mathrm{v}_{\mathrm{r}}}\right)\left(\frac{\mathrm{s}_{\mathrm{o}}-\mathrm{s}}{\mathrm{xv}}\right)
$$

If the term $U$ is substituted for the term $\frac{r_{\text {su }}}{\left(x_{v}\right)}$, the resulting equation is: 


$$
\frac{1}{\theta_{c}}=\mathrm{Y}(\mathrm{c})-\mathrm{K}_{\mathrm{d}}
$$

A term closely related to the specific utilization rate, $\mathrm{U}$ and commonly used in practice and design and control parameter is known as the Food-Microorganism ratio $(\mathrm{F} / \mathrm{M})$, which is defined as follows:

$$
\frac{\mathrm{F}}{\mathrm{M}}=\frac{\mathrm{S}_{\mathrm{o}}}{\theta \mathrm{X}_{\mathrm{v}}}
$$

The term $\mathrm{U}$ and $\mathrm{F} / \mathrm{M}$ are related by the process efficiency as follows:

$\mathrm{U}=\frac{\left(\frac{\mathrm{F}}{\mathrm{M}}\right)(\mathrm{E})}{100}$

where, $E$ is the process efficiency $=\frac{S_{o}-S}{S_{o}}$.

The relation between (V.L.) and (F/M) is:

V.L. $=\frac{\left(\frac{\mathrm{F}}{\mathrm{M}}\right)(\mathrm{XV})}{1000}$

where, V.L. is the volumetric loading.

The basic settling characteristic is the so-called Zone Settling Velocity (ZSV). The zone settling velocity represents a maximum rate of sedimentation and can be expressed as a slope of the linear part of the sedimentation curve. The sedimentation curve can be obtained by measuring the velocity of movement of a sludge-supernatant interface motion in high calibrated cylinders. ZSV depends on sludge concentration.

Another operational approach for solids control, like the sludge age, is the Mean Cell Residence Time (MCRT) or Solids Retention Time (SRT). This parameter is a refinement of the sludge age and takes into consideration the total solids inventory in the secondary or biological system. The desired MCRT for petrochemical wastewater must be found experimentally just like the sludge age.

The MCRT is calculated as:

$$
\begin{aligned}
& \text { Suspended solid in total } \\
& \operatorname{MCRT}\left(\theta_{\mathrm{c}}\right)=\frac{\text { system, } \mathrm{mg}}{\text { S.S.wasted, } \frac{\mathrm{mg}}{\mathrm{day}}+\mathrm{S} . S, \text { lost in }} \\
& \text { effluent, } m g \text { day }^{-1}
\end{aligned}
$$

\section{RESULTS}

The results of Petrochemical wastewater in Basrah treatment plant show that optimum rate of BOD removal could be obtained at food to microorganism ratio between $0.1-0.15$ as shown in Fig. 2 and 3 where this optimum ratio exists at the maximum zone settling velocity as well as that the experimental work show that if MLSS concentration increases, the effluent BOD5 decreases where the design effluent BOD5 could be obtained at a MLSS concentration of $6000 \mathrm{mg} \mathrm{L}^{-1}$ and in about 26-30 day of mean cell residence time as shown in Fig. 4 and 5 .

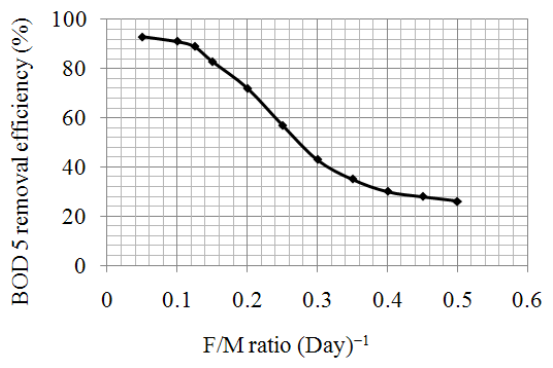

Fig. 2: Effect of Food to microorganism ratio on BOD5 removal efficiency

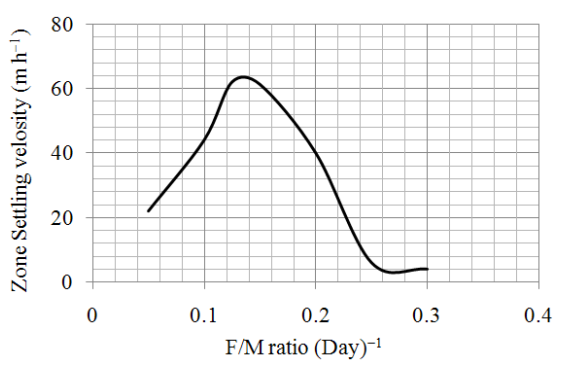

Fig. 3: Effect of Food to microorganism ratio on settling velocity

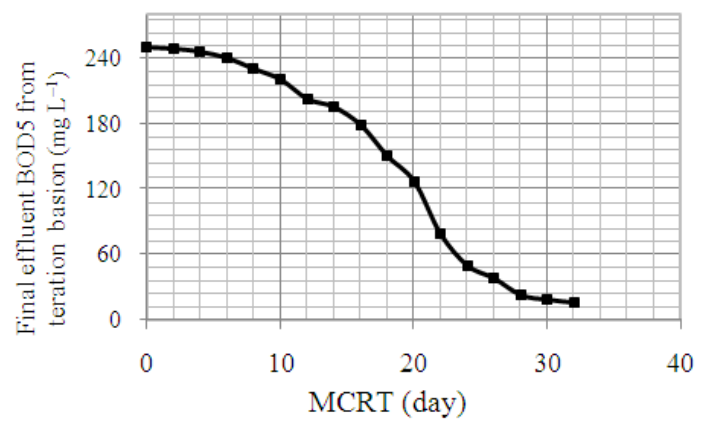

Fig. 4: Effect of mean cell residence time on final effluent BOD5 


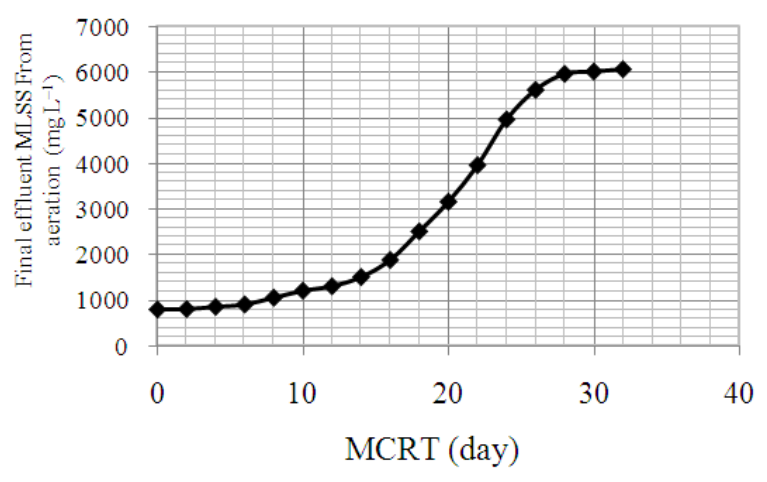

Fig. 5: Effect of mean cell residence time on final effluent mixed liquor suspended solid

\section{DISCUSSION}

One of the easiest control procedures for activated sludge systems is the Constant Mixed Liquor Suspended Solids method. In this method, the operator selects a certain MLSS concentration or range of mix liquor concentrations that produce the best effluent and the highest removal efficiencies. This specific value or range must be determined experimentally. When the operator finds the optimum MLSS concentration for each plant, he attempts to maintain this value by adjusting the sludge wasting rate. One rule of thumb for activated sludge systems is that for every pound of BOD removed in the secondary system a half a pound of new solids is generated through reproduction of the organisms and addition of new organisms from the influent wastes. So, the operator tries to waste the proper amount of solids to keep his selected optimum mix liquor concentration constant. If the MLSS concentration is above the desired concentration, wasting of the excess solids will have to be started or increased. If the MLSS concentration is below the desired concentration level, wasting should be decreased or stopped. The Food/Mass or the Food/Microorganism ratio commonly referred to as $\mathrm{F} / \mathrm{M}$ is based upon the ratio of food fed to the microorganisms each day to the mass of microorganisms held under aeration. It is a simple calculation, using the results from the influent BOD test to the aerator and the mixed liquor suspended solids test.

\section{CONCLUSION}

Experimental data for petrochemical wastewater indicate some important conclusions:

- The optimum removal efficiency of BOD5 could be obtained at food to microorganism ratio between $0.1-0.15$ (day) $^{-1}$ where this optimum ratio exists at the maximum zone settling velocity

- The desired effluent $\mathrm{BOD}_{5}$ Could be obtained at sludge age 28 days and mixed liquor suspended solid $6000 \mathrm{mg} \mathrm{L}^{-1}$

- The extend aeration method of activated sludge process offers the most desirable features for treatment of petrochemical wastewater where the specification of extended aeration method was comply with experimental results.

\section{REFERENCES}

Clescerl, L.S., A.E. Greenberg and A.D. Eaton, 1991. Standard Methods for the Examination of Water and Wastewater. 20th Edn., American Public Health Association, USA., ISBN: 10: 0875532357, pp: 1325 .

Melcer, H., 2003. Methods for wastewater in activated sludge modeling. Water Environmental Research Foundation.

Orhon, D., F.G. Babuna and O. Karahan, 2009. Industrial, Wastewater Treatment by Activated Sludge. IWA Publishing, UK., ISBN: 10: 1843391449, pp: 404.

Ralph, L.S. and J.B. Blackburn, Jr., 1997. The Industrial wastewater systems Handbook. 1st Edn., CRC Press, USA., ISBN: 1-56670-209-7, pp: 544.

Tchobanoglous, G., F.L. Burton and H.D. Stensel, 2002. Wastewater Engineering: Treatment and Reuse. 4th Edn., McGraw-Hill, New York, ISBN: 10: 007124140X, 1848. 